\title{
PELATIHAN EMOTION COACHING UNTUK MENINGKATKAN KETRAMPILAN GURU MERESPON EMOSI ANAK USIA DINI
}

\author{
Astinah 1 \\ Hepi Wahyuningsih ${ }^{2}$ \\ Ratna Syifa'a Rachmahana \\ Program Magister Profesi Psikologi (S2) \\ Universitas Islam Indonesia \\ Yogyakarta
}

\begin{abstract}
This research aims to observe how the emotion coaching training improve the skill of teachers on Education for Early-Age Children (known as PAUD). It uses the design of nonrandomized pretest-posttest control group design. Twelve teachers of PAUD were involved as the participants in this research and they were divided into two groups: 6 of those 12 teachers included in experimental and control group. The measurement tools used in this research were the scale of the skill of teacher response and observation on checklist behavior made by the researcher based upon the theory of Swartz and Mcelwain (2012).. The test of hypothesis used the Friedman analysis. The results of the research showed that the training of emotion coaching can improve the skill of teachers in responding the emotion of early age children before and after giving the training to the experiment group at ( $p=0.002$ where $p<0.05)$.
\end{abstract}

Keywords: Early Age Children, Emotion coaching, Teacher response skills

\begin{abstract}
ABSTRAK: Penelitian ini bertujuan untuk mengetahui dampak pelatihan emotion coaching dalam meningkatkan keterampilan guru PAUD dalam merespon emosi anak. Penelitian ini menggunakan desain nonrandomized pretes-posttest control group design yang melibatkan 12 guru yang dibagi menjadi dua kelompok: 6 guru di kelompok eksperimen dan 6 guru di kelompok kontrol. Alat ukur yang digunakan ialah skala keterampilan respon guru dan observasi checklist behavior yang dibuat sendiri oleh peneliti berdasarkan teori Swartz dan Mcelwain (2012). Uji hipotesis menggunakan analisis Friedman. Hasil penelitian ini menunjukkan bahwa pelatihan emotion coaching terbukti meningkatkan keterampilan guru dalam merespon emosi anak usia dini sebelum dan sesudah diberi pelatihan pada kelompok eksperimen $(p=0.002$ dimana $p<0.05)$.
\end{abstract}

Kata Kunci: Anak Usia Dini, , Emotion coaching, Keterampilan Respon Guru

\footnotetext{
${ }^{1}$ Korespondensi mengenai artikel dapat melalui astinahamirasyah@yahoo.com

2 hepi.habibi@gmail.com
} 
Perkembangan emosi anak merupakan hasil interaksi dengan lingkungan. Berns (2004) mengemukakan bahwa sejumlah sistem yang berpengaruh terhadap perkembangan anak yaitu mikrosistem, mesosistem, ekosistem, makrosistem, dan kronosistem. Salah satu sistem yang paling menonjol dan berpengaruh terhadap perkembangan emosi anak adalah mikrosistem. Dalam mikrosistem terjadi interaksi secara langsung dengan orang lain dan saling mempengaruhi. Agen sosial yang berperan langsung dalam lingkungan tersebut adalah orang tua, guru, dan teman sebaya. Interaksi keduanya menunjukkan konteks yang paling menonjol dalam perkembangan emosi anak.

Guru sebagai subtitusi dari orang tua di sekolah memiliki peran yang kompleks dalam memberikan stimulus, memotivasi, dan sebagai agen pembentukan perilaku siswa sehingga guru yang diharapkan adalah yang kompeten dalam mendidik. Hyson (Kiliç, 2015) berpendapat bahawa guru PAUD berperan penting bagi perkembangan emosi anak dengan menciptakan lingkungan yang mendukung anak dalam meregulasi emosi dan bereaksi secara tepat terhadap perasaan orang lain. Ashiabi (2000) menjelaskan bahwa guru anak usia dini berkontribusi pada perkembangan emosi anak seperti orang tua dalam berbagai peran dalam merespon emosi anak usia dini. Ditegaskan pula oleh Denham, Basset, dan Zinsser (2012) bahwa guru di sekolah memiliki tanggung jawab merespon emosi anak usia dini dengan tepat bahkan dituntut untuk mensosialisasikan emosi kepada anak usia dini. Anak belajar mengamati ekspresi emosi guru yang memberikan contoh yang baik, sehat, adaptif, komunikatif dan perilaku sesuai dengan tuntutan sosial.

Respon guru terhadap emosi anak memengaruhi pemahaman anak dengan berbagai bentuk emosi. Selain itu, respon guru terhadap emosi anak menjadikan anak mampu mengutarakan perasaannya dengan kosa kata emosi. Ahn (2005) menjelaskan bahwa respon guru terhadap emosi anak usia dini merupakan kemampuan guru dalam memberikan tanggapan terhadap ekspresi emosi anak baik positif maupun negatif dengan memberikan pujian, sentuhan, ataupun tanggapan verbal lainnya yang menunjukkan rasa perhatian kepada perasaan anak. Adapun Swartz dan Mcelwain (2012) mendefinisikan respon guru sebagai bentuk sensivitas guru dalam memberikan tanggapan terhadap emosi anak usia dini secara langsung.

Swart dan Mcelwain (2012) mengemukakan tiga dimensi respon guru yaitu respon positif (supportive composite), respon negatif (nonsupportive composite) dan respon lainnya (others composite) yang bisa bersifat positif atau negatif. Dalam ketiga dimensi tersebut terdapat sembilan 5 bentuk respon positif, 2 bentuk respon negatif, dan 2 respon lainnya yaitu; guru menunjukkan ekspresi yang sama dengan ekspresi anak usia dini (match effect), guru memberikan sentuhan fisik kepada anak usia dini (physical affection), guru membantu anak menamai perasaan yang dirasakan oleh anak usia dini (label emotion), guru memberikan dukungan verbal pada ekspresi emosi anak usia dini (verbal support), guru membantu anak menyelesaikan konflik yang sedang dialami oleh anak (problem solve), guru membatasi dan menghukum anak saat mengekspresikan perasaannya (discourage emotion), guru tidak menunjukkan respon apapun terhadap ekspresi emosi anak usia dini (no response), guru mengalihkan perhatian anak saat mengalami emosi (disctract), dan guru meminta anak mencari bantuan kepada orang lain saat anak mengekspresikan emosinya (seek support).

Respon guru terhadap emosi anak usia dini sejalan dengan kompetensi guru dalam peraturan Departemen Pendidikan 
Nasional (2007) bahwa kompetensi profesional guru PAUD di mana guru dituntut dapat berkegiatan dan memiliki program yang sesuai dengan kebutuhan dan perkembangan anak usia dini termasuk perkembangan emosi dan sosial anak. Sementara itu, kompetensi kepribadian meliputi kepekaan guru terhadap perasaan anak dan pikiran anak, menghargai perbedaan, cepat tanggap dengan kesulitan anak, memiliki rasa peduli, empati dan responsif serta memberi dorongan pada anak. Sehingga dapat disimpulkan bahwa guru dituntut untuk responsif terhadap perasaan anak untuk dapat membantu anak mengenali berbagai macam emosi.

Namun terdapat kesenjangan kompetensi dan realita pada guru dalam mengajarkan emosi terhadap usia dini di sekolah. Capaian perkembangan emosi anak usia dini tampak belum optimal pada siswa PAUD "Kc". Astinah (2017); Elwan (2017); dan Fitriana (2017) dalam penelitiannya menemukan kondisi siswa Taman KanakKanak "Kc" dengan perilaku agresif seperti perilaku mengganggu teman, tidak mau berkompromi dengan aturan di sekolah, tantrum, regulasi emosi rendah, oppositional defiant disorder (ODD), namun adapula yang berperilaku sebaliknya yaitu anak-anak kurang mampu mengekspresikan perasaan sehingga cenderung pasif dalam berinteraksi. Guru di sekolah tersebut kurang mampu menangani emosi anak dengan mengalihkan perasaan anak ketika mengalami emosi negatif, meminta anak berhenti menangis tanpa disertai alasan, membiarkan anak terdiam, serta tidak responsif dengan ekspresi emosi negatif lainnya.

Dengan demikian, perlu adanya peningkatan keterampilan guru dalam merespon emosi anak usia dini di sekolah. Hal tersebut dapat dilakukan dengan adanya pelatihan. Beberapa penelitian telah menguji efektivitas pelatihan emotion coaching dalam meningkatkan keterampilan orang tua maupun guru dalam merespon serta mengajarkan emosi yang tepat pada anak usia dini. Penelitian ini fokus pada emotion coaching yang dapat dilakukan oleh guru kepada anak usia dini di sekolah yang bersifat preventif. Emotion coaching dipopulerkan oleh Gottman dan DeClaire (1997) sebagai proses edukasi emosi yang dilakukan orang tua untuk membantu anak mengenali emosinya sendiri, mengenali emosi orang lain, dan mengelola emosinya sendiri sehingga mudah beradaptasi dan responsif terhadap aktivitas di lingkungannya. Diharapkan emotion coaching yang diberikan oleh guru membantu merespon ekspresi emosi anak, sehingga anak belajar mendengarkan secara eksplisit perasaannya sendiri, mencari solusi yang membantunya mengelola perasaannya, mengetahui konsekuensi dari perilaku dan anak menjadi lebih proaktif meningkatkan kompetensi sosial dan emosi. Pelatihan emotion coaching terbukti membantu anak dalam meregulasi emosi, sebagaimana dibuktikan dalam penelitian Kloes (2015) terhadap guru TK Inklusif di Wilayah Pasifik Barat. Tak hanya pada guru, penelitian yang dilakukan Intan, Kurniawati, dan Handayani (2017) menerapkan pelatihan emotion coaching ini pada orang tua dan ternyata juga mampu meningkatkan pengetahuan dan ketrampilan mereka dalam merespon momen emosi anak usia 46 tahun. Orangtua mampu menebak dengan tepat emosi yang ditampilkan anak, memanfaatkan momen emosi pada anak usia dini, mendengarkan perasaan anak dengan penuh empati dan anak menyatakan perasaannya secara verbal. Berdasarkan gambaran permasalahan di atas, peneliti ingin mengetahui apakah pelatihan emotion coaching dapat meningkatkan keterampilan guru dalam merespon emosi anak usia dini? Dengan demikian, penelitian ini mengambil judul "Pelatihan Emotion Coaching untuk Meningkatkan Keterampilan Guru dalam Merespon Emosi Anak Usia Dini". 


\section{METODE PENELITIAN}

\section{Desain Penelitian}

Penelitian ini menggunakan metode eksperimen. Adapun rancangan eksprimen yang digunakan dalam penelitian ini adalah nonrandomized pretest-posttest control group design. Desain eksprimen tersebut berusaha membandingkan efek perlakuan terhadap variabel tergantung yang diuji dengan membandingkan variabel tergantung pada kelompok eksperimen setelah dikenai perlakukan dengan kelompok kontrol yang tidak dikenai perlakuan.

\section{Subjek Penelitian}

Subjek yang terlibat dalam penelitian ini adalah 12 guru yang mengajar di dua PAUD berbeda di Kabupaten Sleman, Yogyakarta, dengan kategori keterampilan respon terhadap emosi anak usia dini yang rendah atau sedang. Dari 12 subjek tersebut dibagi masing-masing 6 orang yang masuk dalam kelompok eksperimen, dan 6 orang lagi masuk sebagai kelompok kontrol.

\section{Metode Pengumpulan Data}

Metode pengumpulan data dalam penelitian ini menggunakan skala keterampilan respon guru dan checklist behavior respon guru yang didasarkan teori Swartz dan Mcelwain (2012). Dimensi respon terdiri dari tiga yaitu respon positif (supportive composite), respon negatif (nonsupportive composite), dan respon lainnya (other composite) yang dapat bersifat respon positif atau negatif. Ketiga dimensi tersebut diukur kemampuan guru dalam menunjukkan ekspresi emosi yang sama dengan anak (match effect), memberikan sentuhan fisik (physical affection), membantu anak melabeli perasaannya (label emotion), memberikan dukungan secara verbal (verbal support), membantu anak menyelesaikan masalahnya (problem solve), membatasi, melarang, menghukum anak saat mengekspresikan emosi (discourage emotion), mengalihkan perhatian anak saat mengalami emosi (dictract), meminta anak mencari bantuan kepada orang lain dan guru (seek support), dan tidak menunjukkan respon apapun saat anak mengalami emosi, baik positif maupun negatif (no response). Observasi pada checklist behavior dilakukan selama 3 hari seminggu sebelum pelatihan (prates), 3 hari setelah seminggu pelatihan (pascates), dan 3 hari setelah dua minggu pascates (follow up). Observasi dilakukan dalam durasi 150 menit. Setiap responden diobservasi oleh dua orang observer.

\section{Prosedur Intervensi}

Pelatihan emotion coaching didasarkan komponen utama dari teori emotion coaching oleh Gottman dan DeClaire (1997). Empati dan kesadaran sebagai komponen utama kemudian terbagi dalam beberapa langkah-langkah konkret meliputi; kemampuan menyadari emosi yang muncul pada anak (being aware of the child's emotions), menjadikan emosi untuk membangun kedekatan dan mengajarkan emosi pada anak (recognize the emotion an opportunity for intimacy and teaching), mendengarkan dengan empati dan memvalidasi emosi anak (listen the empathetically and validating the child's feeling), membantu anak melabeli perasaannya (help the child find words to label the emotion he is having), dan menentukan batasan perilaku yang pantas dalam mengekspresikan emosi serta membantu anak mencari solusi (set limits while exploring strategies to solve the problem at hand). Pelatihan yang dibuat peneliti dengan memberikan singkatan atas langkah-langkah emotion coaching dengan sebutan CARE yaitu; Connect, Accept \& listen empathetically, Reflect \& label emotion, and End with solving problem and set limit. Pelatihan dilaksanakan selama tiga hari sebanyak lima sesi yaitu; (1) teachers on 
training, (2) teacher role on pre schoolers emotion, (3) emotion coaching: teaching to CARE (teaching to Connect, teaching to Accept \& Listen empathetically, teaching to Reflect \& Label the emotions, dan teaching to End with solve the problem \& Set limit). Pelatihan menggunakan metode ceramah, diskusi, role play, video tentang emotion coaching, dan responden penelitian diberikan take home untuk mengaplikasikan secara langsung hasil pelatihan. Adapun pemateri pelatihan dilakukan Psikolog Pendidikan dan Perkembangan Anak.

\section{Teknik Analisis Data}

Analisis data kuantitatif menggunakan program SPSS 16.0 for windows. Teknik analisis data yang digunakan adalah analisis statistik non parametrik Friedman dan Mann-Whitney. Analisis data dengan Friedman untuk mengetahui ada tidaknya pengaruh pelatihan yang diberikan. Selain itu, dilakukan analisis data dengan teknik Mann-Whitney untuk menguji perbedaan skor antara dua sampel independen (unrelated sample), yaitu untuk menguji apakah ada perbedaan keterampilan guru dalam merespon emosi anak usia dini pada saat prates dan pascates antara kelompok eksperimen dan kelompok kontrol.

\section{PEMBAHASAN}

Penelitian ini bertujuan untuk meningkatkan keterampilan guru merespon emosi anak usia dini melalui intervensi berupa pelatihan emotion coaching. Penelitian tentang emotion coaching didasarkan dari pengasuhan orangtua, namun beberapa tahun terakhir pelatihan emotion coaching diberikan kepada guru anak usia dini untuk menjadikan guru lebih terampil merespon emosi anak di sekolah. Namun penelitian mengenai emotion coaching di Indonesia masih sangat terbatas di Kota Yogyakarta belum ditemukan pelatihan emotion coaching kepada orangtua maupun guru di sekolah. Penelitian ini melibatkan guru PAUD pada dua sekolah yang berbeda terdiri dari 6 subjek penelitian dari kelompok eksperimen dan 6 subjek penelitian dari kelompok kontrol.

Temuan dalam penelitian ini mengungkapkan bahwa pelatihan emotion coaching meningkatkan keterampilan guru merespon emosi anak usia dini dengan nilai signifikansi sebesar $0.002(\mathrm{p}<0.05)$. Temuan tersebut didukung penelitian yang dilakukan Intan, Kurniawati, dan Handayani (2017) bahwa keterampilan guru merespon emosi yang tepat, didukung dengan emotion coaching berupa menerima perasaan, berempati dengan perasaan anak, memahami batasan perilaku dan ekspresi anak yang pantas dan tidak pantas.

Berdasarkan hasil penelitian, diketahui bahwa terdapat perbedaan yang signifikan berdasarkan skor ketrampilan respon guru $\mathrm{p}=0.005 \quad(\mathrm{p}<0.05)$ pada kelompok eksperimen dan kelompok kontrol. Kelompok eksperimen mengalami peningkatan ketrampilan merespon emosi anak usia dini setelah mengikuti pelatihan emotion coaching apabila dibandingkan dengan kelompok kontrol yang tidak mengikuti pelatihan. Hal tersebut dapat dilihat dari hasil pengukuran prates ke pascates dalam kelompok eksperimen secara signifikan $\mathrm{p}=0.027 \quad(\mathrm{p}<0.05)$ sementara hasil pengukuran prates ke pascates dalam kelompok kontrol menunjukkan nilai yang tidak signifikan $p=0.206(p>0.05)$. Hasil penelitian tersebut menunjukkan bahwa terdapat peningkatan keterampilan guru merespon emosi anak pada kelompok eksperimen setelah diberikan pelatihan. Pada kelompok Kontrol, tidak terjadi peningkatan sebab tidak diberikan pelatihan.

Beberapa pelatihan emotion coaching terbukti meningkatkan keterampilan orang tua dalam merespon emosi anak. Intan, Kurniawati, dan Handayani (2017) dalam penelitiannya memaparkan bahwa orangtua menjadi lebih berempati dengan anak 
sehingga mampu menebak perasaan anak, serta menjadikan orangtua mampu memvalidasi dan membantu anak menamai perasaan yang sedang dialaminya saat itu juga. Contoh perubahan dalam menanggapi perasaan takut di antaranya ialah sebelum pelatihan, orangtua mengatakan "tidak usah takut" namun setelah pelatihan ucapan tersebut diganti dengan "kamu takut ya?".

Demikian pula dengan penelitian LaBass (2016) bahwa program HTK (How to Talk to Kids so Kids Will Listen-Video Series) yang disertai dengan emotion coaching menjadikan peserta mengalami perubahan persepsi tentang emosi negatif yang dialami anak. Terdapat penurunan skor dalam respon orangtua yang menekannya dari ekspresi negatif anak. Selain itu, terdapat penuruan skor respon orangtua yang memicunya untuk memberikan hukuman pada anak, merendahkan, mengkritisi dan membatasi ekspresi emosi anak. Sebaliknya terjadi peningkatan skor pada respon orangtua yang mendukung ekspresi emosi anak, memvalidasi perasaan negatif yang dialami oleh anak, orangtua membantu anak memecahkan masalah dan peningkatan skor pada respon orangtua yang membuat anak kembali nyaman.

Pencapaian dalam penelitian ini berupa peningkatan keterampilan guru disertai dengan meningkatnya kesadaran dan empati guru. Peserta KE01 menyadari bahwa mengajarkan emosi pada anak bisa dilakukan saat anak sedang mengalami emosi. Peserta KE02 mengutarakan kesadarannya setelah mengikuti pelatihan yaitu mulai menyadari bahwa fokus dengan menyelesaikan masalah anak ternyata tidak sepenuhnya membantu anak dalam mengenali emosinya. Selain itu, KE05 menyadari akan pentingnya memulai mengenalkan anak berbagai nama emosi saat anak sedang mengalami emosi secara langsung agar lebih berkesan bagi anak.

Kondisi demikian menjadikan guru menyadari perannya dalam mengenalkan emosi saat anak mengalami emosi negatif saat itu juga. Kesadaran yang dimiliki oleh guru setelah mengikuti pelatihan emotion coaching sejalan dengan penelitian Kloes (2015) bahwa emotion coaching meningkatkan kesadaran guru dalam membantu anak mengenali berbagai macam emosi dan mengoptimalkan perkembangan emosinya sendiri.

Peningkatan ketrampilan guru dalam merespon emosi anak usia dini setelah mengikuti pelatihan emotion coaching juga meningkatkan empati guru. Stojiljković, Djigić dan Zlatković (2012) mengemukakan bahwa empati menjadi karakteristik penting bagi guru yang memungkinkan terbentuknya komunikasi yang memadai dengan siswa dalam proses belajar. Empati merupakan salah satu kunci guru dalam membantu iklim kelas yang menjadikan siswa merasa senang, bebas, merasa dilibatkan, merasa dihormati dan merasa dipahami. Hal ini sejalan dengan Gottman dan DeClaire (1997) bahwa empati membantu guru memiliki perspektif yang sama dengan perasaan anak sehingga mampu merespon emosi anak dengan tepat. Temuan di lapangan juga menggambarkan hal yang sama, responden penelitian merasa bahwa setelah mengikuti pelatihan emotion coaching ia berusaha untuk menempatkan dirinya dalam posisi anak sehingga lebih fokus terhadap perasaan anak bukan pada masalah yang dimiliki anak.

Sementara itu, subjek KE04 menyampaikan dalam wawancara bahwa ia berusaha untuk menghadirkan perasaan empati lebih dari sebelumnya saat beraktivitas bersama anak di sekolah agar dapat merespon emosi anak sesuai dengan apa yang sedang dirasakannya sehingga meminimalkan respon yang langsung menyelesaikan masalah anak. Hal ini sejalan dengan tujuan utama pelatihan emotion coaching.

Gus, Rose dan Gilbert (2015) mengungkapkan bahwa emotion coaching bermanfaat untuk menyempurnakan 
hubungan antara siswa dan guru dimana siswa lebih percaya dengan guru yang mendorongnya mengekspresikan perasaan, membantu menamai perasaannya, membantu siswa memahami dan menyelesaikan konflik. Hal tersebut didorong dengan perubahan perasaan guru yang lebih berempati, menjadi lebih proaktif, dan lebih berhati-hati menghadapi emosi anak. Gus dkk (2017) menambahkan bahwa emotion coaching membantu guru lebih berempati dengan perasaan anak sehingga dapat memberikan respon yang tidak impulsif namun sebaliknya lebih mempertimbangkan mengapa anak menjadi sedih, marah, kecewa, ataupun perasaan lainnya

Menurut Cooper (2004) perasaan empati dapat terlihat dari suatu respon kepedulian terhadap perasaan orang lain. Dalam seting pendidikan anak usia dini, empati tampak dari kemampuan guru untuk memahami bahasa tubuh anak-anak misalnya anak tersenyum lebar, menangis, menutup muka, mengepalkan tangan, menghentakkan kaki ataupun ekspresi lainnya. Pengamatan guru yang demikian akan memudahkan baginya untuk memiliki sudut pandang yang sama dengan perasaan anak sehingga dapat mengakui perasaan anak dan membantunya menamai perasaannya. Swart dan Mcelwain (2012) menambahkan bahwa empati sangat membantu guru dalam memberikan dukungan verbal terhadap emosi anak usia dini termasuk membantu anak menamai perasaan yang dimilikinya.

Peningkatan kesadaran dan empati setelah pelatihan emotion coaching sangat mendukung hasil penelitian khususnya dalam meningkatkan respon positif dan menurunkan respon negatif. Hal ini ditunjukkan dari skor analisis statistik pada dimensi respon guru, respon positif (supportive composite): nilai $\mathrm{p}=0.006(\mathrm{p}<$ 0.05) dan pada respon negatif (nonsupportive composite): nilai $\mathrm{p}=0.023(\mathrm{p}$
$<0.05)$ serta respon lainnya (others composite): nilai $\mathrm{p}=0.009(\mathrm{p}<0.05)$. Artinya, pelatihan emotion coaching secara signifikan mempengaruhi keterampilan guru dalam merespon emosi anak usia dini.

Respon positif (supportive composite) dalam penelitian ini mengacu pada Swart dan Mcelwain (2012), meliputi kemampuan guru menunjukkan ekspresi yang sama dengan perasaan anak (match effect), guru memberikan sentuhan pada anak (physical affection), guru menamai perasaan anak (label emotion), guru memberikan dukungan terhadap ekspresi emosi anak (verbal support), dan momen guru berdiskusi dengan anak tentang berbagai alternatif solusi dalam merespon emosi atau situasi anak (problem solve). Sebaliknya, respon negatif (nonsupportive composite) serta respon lainnya (others composite) yang bersifat negatif. Respon tersebut berupa membatasi, melarang, atau menghukum anak yang mengekpresikan emosi dengan verbal maupun non-verbal (discourage emotion), guru mengalihkan perasaan negatif anak (distract), guru meminta bantuan kepada guru lain saat anak merasakan emosi negatif (seek support), dan guru tidak memberikan respon apapun terhadap ekspresi emosi anak (no respon).

Beberapa penelitian sebelumnya menjelaskan bahwa pelatihan emotion coaching meningkatkan respon guru maupun orangtua terhadap ekspresi emosi anak usia dini. Kloes (2015) menemukan bahwa pelatihan emotion coaching membantu guru lebih terampil dalam membantu anak menamai perasaannya. Sebelum pelatihan, guru dalam penelitian Kloes saat observasi hanya memberikan 2 3 kosa kata emosi. Sebaliknya, setelah pelatihan maka penggunaan kosa kata verbal dan menamai emosi anak dapat diberikan minimal 5 kosa kata emosi. Hal ini sejalan dengan penelitian Gus dkk (2017) bahwa pengenalan emotion coaching meningkatkan kemampuan guru dalam 
mendorong siswa untuk menamai perasaan yang dialami oleh anak.

Respon positif yang meningkat dan menurunnya respon negatif dalam penelitian ini juga didukung oleh penelitian lainnya. Berdasarkan penelitian LaBass (2016) respon positif berupa dorongan mengekspresikan perasaan anak dan penyelesaian masalah yang melibatkan anak mengalami peningkatan. Hal tersebut terbukti dengan adanya kecenderungan peserta dalam mendengarkan, menerima dan memberikan empati serta memvalidasi emosi negatif yang dialami anak. Selain itu, peserta cenderung mendorong anak-anak mengekspresikan emosi negatif dan menemukan solusi terhadap permasalahan anak. Sementara itu, respon negatif mengalami penurunan setelah peserta mengikuti pelatihan berupa respon yang mengukum dan membatasi ekspresi emosi anak usia dini.

Hasil penelitian yang cukup signifikan juga dipengaruhi oleh metodologi, di antaranya dipengaruhi pemilihan subjek penelitian, rancangan eksperimen yang digunakan, alat ukur yang digunakan, dan kegiatan pelatihan. Dalam hal pemilihan subjek penelitian, peserta pelatihan mengikuti kegiatan secara sukarela dan tidak ada paksaan. Selain itu, pelatihan emotion coaching sesuai kebutuhan guru anak usia dini dalam mengembangkan kompetensi mereka sebagai guru. Kompetensi yang dimaksud dalam hal ini adalah kompetensi kepribadian dan kompetensi profesional.

Departemen Pendidikan Nasional (2007) mengatur salah satu subkompetensi profesional adalah penguasaan guru anak usia dini dengan kegiatan dan program yang sesuai dengan kebutuhan dan perkembangan anak usia dini termasuk perkembangan emosi dan sosial anak usia dini. Sementara itu, kompetensi kepribadian meliputi kepekaan guru terhadap perasaan dan pikiran anak, menghargai perbedaan, cepat tanggap dengan kesulitan anak, memiliki rasa peduli, empati dan responsif serta memberi dorongan kepada anak. Kesesuaian kebutuhan guru dengan pelatihan yang diberikan, memantik antusiasme responden penelitian dalam mengikuti pelatihan emotion coaching. Uraian tersebut sejalan dengan pendapat Gus dkk (2015) bahwa pelatihan emotion coaching berkontribusi kepada guru untuk lebih profesional dengan tidak terlalu tertarik dengan permasalahan siswa namun lebih kepada mengajari siswa tentang emosi dan menjadikan mereka secara bertahap mengalanisis perasaannya sehingga menjadi lebih mandiri.

Adapun rancangan penelitian ini ialah menggunakan kelompok kontrol dari sekolah berbeda sebagai pembanding kelompok eksperimen, agar meminimalkan efek interaksi yang terjadi di antara keduanya. Minimnya efek interaksi ini berdampak positif pada validitas hasil penelitian. Namun, terdapat variabel yang tidak dapat dikendalikan peneliti saat dua subjek penelitian (KK 01 dan KK06) mengikuti pelatihan "Penanaman Nilai-Nilai Moral dan Karakter Anak Usia Dini" dalam rentang waktu pasca tes ke tindaklanjut (follow up). Sehingga kelompok kontrol juga secara signifikan mengalami peningkatan respon guru meskipun tidak diberikan pelatihan dari pengukuran pasca tes ke Tindaklanjut

Menurut Latipun (2017) bahwa dalam penelitian eksperimen khususnya bidang psikologi sangat sulit untuk menghilangkan pengaruh variabel non-eksperimental. Seperti dalam penelitian ini, peneliti tidak mampu mengendalikan variabel tidak terkontrol (extraneous variable) berupa pelatihan yang diikuti oleh dua subjek penelitian dari kelompok kontrol yang memungkinkan bertambahnya pengetahuan dan pengalaman serta penyebaran informasi terhadap responden kelompok kontrol yang lain. Namun, peningkatan skor hanya pada 
taraf skala ketrampilan respon guru tidak disertai dengan peningkatan yang signifikan pada observasi ketrampilan respon guru terhadap emosi anak usia dini pada kelompok kontrol.

Reliabilitas dan validitas dalam skala keterampilan respon guru cukup mampu mendeteksi skor ketrampilan respon guru. Hanya saja, alat ukur yang digunakan memiliki kekurangan dalam hal reliabilitas yang rendah sehingga ada baiknya peneliti selanjutnya melakukan uji coba dengan subjek penelitian yang lebih banyak sehingga pernyataan di aitem lebih dapat terdistribusi dengan baik. Selain itu, alat ukur berupa check list behavior respon guru butuh dibenahi dengan menentukan emosiemosi tertentu yang menjadi target observasi sehingga observasi respon guru bisa lebih spesifik terhadap beberapa emosi siswa. Hal ini dapat merujuk kepada alat ukur yang digunakan LaBass (2016) dalam disertasinya. Selain itu, observer penelitian idealnya diberikan training secara langsung dalam mengamati guru dan anak-anak di sekolah sebelum melakukan observasi agar lebih dapat membedakan jenis-jenis respon guru serta memiliki kesamaan persepsi dengan observer lainnya.

Hasil penelitian ini tidak terlepas dari kegiatan pelatihan emotion coaching yang menerapkan pendekatan experimental learning. Pelatihan memuat berbagai kegiatan aktif seperti metode presentasi, role play, video, diskusi kelompok dan pengerjaan kasus yang mendorong guru untuk berlatih merespon emosi anak usia dini dengan lebih baik. Pelatihan juga didukung dengan pemberian home work kepada responden penelitian untuk mempraktekkan secara langsung responnya kepada anak usia dini selama dua hari saat jeda materi diberikan. Silberman dan Biench (2015) mengemukakan bahwa experimental learning dimana peserta pelatihan dapat belajar dengan baik dengan melihat, mendengar, bertanya, berdiskusi dan mempraktikkannya dalam pelatihan maupun setelah pelatihan. Berbagai temuan yang telah dipaparkan di atas, menunjukkan bahwa pelatihan emotion coaching mampu meningkatkan keterampilan guru dalam merespon emosi anak usia dini.

\section{SIMPULAN DAN SARAN}

Pelatihan emotion coaching terbukti mampu meningkatkan skor ketrampilan guru dalam merespon emosi anak usia dini. Selain itu, terdapat perbedaan yang signifikan antara kelompok eksperimen setelah mengikuti pelatihan dan kelompok kontrol yang tidak mengikuti pelatihan. Hasil observasi subjek penelitian juga menunjukkan adanya peningkatan ketrampilan merespon emosi anak usia dini dengan menggunakan emotion coaching. Sedangkan pada kelompok kontrol tidak terdapat peningkatan yang signifikan. Dengan demikian dapat disimpulkan bahwa hipotesis dalam penelitian ini diterima.

\section{Saran}

Saran dalam penelitian ini ditujukan kepada guru agar terus berlatih mempraktekkan coaching emosi kepada anak usia dini di sekolah. Sementara itu bagi peneliti selanjutnya, dapat menggunakan dan mengembangkan alat ukur yang telah disusun peneliti dengan menggunakan jumlah subjek penelitian lebih banyak dari penelitian ini. Peneliti selanjutnya juga dapat menggunakan dan mengembangkan modul yang telah disusun peneliti sesuai dengan teori yang digunakan. Selain itu, peneliti selanjutnya diharapkan melakukan penilaian terhadap modul yang melibatkan ahli yang berlatar belakang Pendidikan Anak Usia Dini (PAUD). Peneliti selanjutnya juga diharapkan untuk melakukan training kepada observer penelitian sehingga lebih mampu mengindentifikasi bentuk-bentuk ketrampilan respon guru secara langsung dengan lebih tepat sebelum dilakukan pengukuran kepada responden penelitian. 


\section{DAFTAR PUSTAKA}

Ahn, H. J. (2005). Child care teacher's strategies in children's socialization of emotion. Early child Development and Care. 175(1), pp 49-61. DOI: 10.1080/ 0300443042000230320 .

Ashiabi, G., S. (2000). Promoting the emotional development of preschoolers. Early Childhood Education Journal. Vol 28, No. 2.

Astinah. (2017). Oppositional defiant disorder (ODD). Laporan Praktik Kerja Profesi Psikologi: Kasus Individu Jenjang Taman KanakKanak (TK). Magister Psikologi Profesi UII: Tidak diterbitkan.

Berns, R., M. (2004). Child, family, school, community, socialization, and support. 6th edition. USA: Thomson Wadsworth

Cooper, B. (2004). Empathy, interaction and caring: Teachers' roles in a constrained environment. USA. Blackwell Publishing.

Denham, S. A., Basset, H. H., \& Zinsser, K. (2012). Early childhood teachers as social of young children's emotional competence. Early Childhood Education Journal. 40: 137-143. DOI $10.1007 / \mathrm{s} 10643-$ 012-0504-2.

Departemen Pendidikan Nasional. (2007). Peraturan menteri pendidikan nasional nomor 16 tahun 2007 tanggal 4 Mei 2007 standar kualifikasi akademik dan kompetensi guru. Jakarta: Departemen Pendidikan Nasional.
Elwan. T., K., P. (2017). Hambatan perkembangan sosial-emosi. Laporan Praktik Kerja Profesi Psikologi: Kasus Individu Jenjang Taman Kanak-Kanak (TK). Magister Psikologi Profesi UII: Tidak diterbitkan.

Fitriana, R. (2017). Regulasi emosi rendah. Laporan Praktik Kerja Profesi Psikologi: Kasus Individu Jenjang Taman Kanak-Kanak (TK). Magister Psikologi Profesi UII: Tidak diterbitkan.

Gottman, J. \& DeClaire, J. (1997). The heart of parenting. London: Bloomsbury Publishing.

Gus, L., Rose, J. \& Gilbert, L. (2015). Emotion coaching: A universal strategy for supporting and promoting sustainable emotional and behavioral well-being. Educational \& child psychology, 32 (1).

Gus, L., Rose, J., Gilbert, L., \& Kilby, R. (2017). The introduction of emotion coaching as a whole school approach in a primary specialist emotional and mental health setting: positive outcomes for all. The open family studies journal. 9 (Suppl-I, M3) 95 - 110.

Intan, R., Kurniawati, F., \& Handayani, E. (2017). Pelatihan emotion coaching untuk meningkatkan pengetahuan dan keterampilan orangtua dalam merespon momen emosi anak usia 4 - 5 tahun. Jurnal Psikogenesis. 2 (5), 188-198. 
Kiliç, Ş. (2015). Preschool teachers's emotional socialization responses to $4-6$ years-old turkish preschoolers' emotional expressions. Euroupean Journal of Research on Education. 3 (1), 53-63. ISSN: 2147-6284.

Kloes, K. (2015). Emotion coaching in an inclusive setting: Training preschool special educators. Thesis. Master of Education: University of Washington.

LaBass, E. (2016). Does teaching parents emotion-coaching strategies change parental perception of children's negative emotions? Dissertation. Doctor of Psychology. Antioch University Seattle.
Latipun. (2017). Psikologi eksperimen. Edisi keenam. UMM Press: Malang

Silberman, M. \& Biech, E. (2015), Active learning; A handbook of technique, designs, case examples and tips, (4th Ed.), Wiley Tomlinson.

Stojiljković, S., Djigić, G., \& Zlatković, B. (2012). Empathy and teachers' role. Procedia - Social and Behavioral Sciences. 69. 960 - 966.

Swartz, R. A., \& Mcelwain, N. L., (2012). Preservice teacher's emotionregulated regulation and cognition: Associations with teacher's response to children's emotions in early childhood clasroom. Early Education and Development. 23: 202-226 
Astinah, Hepi Wahyuningsih \& Ratna Syifa'a Rachmahana 